\title{
The Microflora of Gills, Gut and Skin of European Eels (Anguilla anguilla) in Lakes of Latvia
}

Vita Strazdina ${ }^{1}$, Margarita Terentjeva ${ }^{2}$, Olga Valcina ${ }^{1}$, Inga Eizenberga ${ }^{1}$, Aleksandr Novoslavskij ${ }^{3}$, Jevgenija Osmjana $^{1}$ and Aivars Berzins ${ }^{1,2}$

1. Latvia Institute of Food Safety, Animal Health and Environment "BIOR", Lejupes Street 3, Riga LV 1076, Latvia

2. Institute of Food and Environmental Hygiene, Faculty of Veterinary Medicine, Latvia University of Agriculture, Helmanga Street 8 , Jelgava LV 3004, Latvia

3. Lithuanian Veterinary Academy, Lithuanian University of Health Sciences, Tilžès Street 18, Kaunas 47181, Lithuania

\begin{abstract}
The microbial contamination of fish is the most important factor in assurance of food safety. The microflora on the surface of skin, gills and gut of fish is constantly under the influence of the water environment and this may cause colonization of microorganisms on fish. The goal of this study was to evaluate the bacterial contamination level on the skin, gills and gut of the European eel (Anguilla anguilla), i.e., detecting total bacteria count (TBC) and Enterobacteriaceae counts, as well as Listeria spp. and Salmonella spp. in freshly caught fish. Among the three lakes, TBC on skin, gills and gut varied from $0.66 \mathrm{CFU} / \mathrm{cm}^{2}$ to 4.93 $\mathrm{CFU} / \mathrm{cm}^{2}$, from $0.40 \mathrm{CFU} / \mathrm{cm}^{2}$ to $5.51 \mathrm{CFU} / \mathrm{cm}^{2}$ and from $0.30 \mathrm{CFU} / \mathrm{cm}^{2}$ to $6.37 \mathrm{CFU} / \mathrm{cm}^{2}$, respectively. Enterobacteriaceae count on skin, gills and gut was from $0 \mathrm{CFU} / \mathrm{cm}^{2}$ to $4.30 \mathrm{CFU} / \mathrm{cm}^{2}$, from $0 \mathrm{CFU} / \mathrm{cm}^{2}$ to $2.47 \mathrm{CFU} / \mathrm{cm}^{2}$ and from $0 \mathrm{CFU} / \mathrm{cm}^{2}$ to $1.72 \mathrm{CFU} / \mathrm{cm}^{2}$, respectively. The highest mean count of TBC on gills, skin and gut was found in samples from Sivers lake, while the lowest was in samples from Aluksne lake. Values among the lakes were significanty $(P<0.05)$ different. Also the highest mean counts of Enterobacteriaceae were found on gills and skin of eels from Sivers lake, but the highest count on gut was found in Usma lake. All tested samples were Listeria monocytogenes and Salmonella spp. negative. TBC and Enterobacteriaceae counts of skin, gills and gut were typical for wild fish in fresh water. Foodborne pathogens, such as Salmonella spp. and L. monocytogenes, have not been found in the present study, indicating that fish are safe for human consumption.
\end{abstract}

Key words: Freshwater fish, lake, microbial contamination, European eel, Salmonella spp., L. monocytogenes.

\section{Introduction ${ }^{1}$}

Nowadays, fish and fish products comprise a significant part of food for the majority of the world population, and fish meat is considered to be healthier alternative to red meat consumption [1,2]. According to the Latvian Statistic Bureau, the consumption of fish and fish products was within the range of 6.0-6.6 $\mathrm{kg}$ /capita between the years 2008 and 2012 in Latvia [3]. Foodborne disease outbreaks related to the consumption of fish and fish products have been reported from the European countries, indicating that the microbiological quality of fish available on market is an important public safety issue [4].

Corresponding author: Vita Strazdina, Dr. ing, research feild: meat and food.
Microbiological quality of fish depends on various factors and the quality of water among those factors has a significant impact on fish microflora. Pollution of the water sources frequently is attributed to contamination with wastewaters from agricultural and human sources [5]. Initial contamination of fish with microorganisms alters fish microbiological quality. After catching the fish, the immune system is collapsed, so it does not delay microbial growth, and post-mortem changes enhance their proliferation on gills, skin and gut [6]. Large numbers of microorganisms are present in fish gills and this is related to aeration processes and access to oxygen for microbial growth. Large amount of available organic compounds as well as slight alkaline environment of gills make water microflora to easily colonize on gills 
[7]. Gut microflora could penetrate intestinal wall under certain conditions and contribute to the spoilage of fish, raising concerns about fitness of product for human consumption [6, 8-10]. In general, fish is more perishable than red meat $[2,11]$, therefore it is necessary to evaluate general contamination rates of freshwater fish available for consumption.

Water as same as food can serve as a vehicle for transmission of pathogens, which potentially can cause different outbreaks of infections worldwide [12]. Microbiological pollution of water can directly affect water inhabitants and fish may be contaminated with foodborne pathogens, such as Salmonella spp. or $L$. monocytogenes, making them unfit for human consumption. Contamination of Salmonella spp. can cause gastrointestinal disorders in human and it may be arisen from agricultural or human sources with subsequent contamination of environment and fish [13, 14]. L. monocytogenes can cause foodborne infection characterized with severe disorders, such as meningitis, encephalitis and septicemia in susceptible population. In opposite to Salmonella, $L$. monocytogenes is a psychrotrophic pathogen and widely distributed in the environment, including inland waters. The presence of these foodborne pathogens in raw product poses the public health concerns, because of cross-contamnation and possibility of transmission of pathogen during processing if the raw material is contaminated [14]. Studies on microbiological contamination of fish are necessary for identification of existing problems and for implementation of preventive measures among consumers, fishermen and retailers [15, 16]. Usma, Sivers and Aluksne lakes are common destinations for individual fishermen, recreational and economical activities in Latvia. However, environmental pollution problems raise concerns about microbiological quality of inland water and subsequently about fish microbiological quality. Therefore, it is important to estimate the environmental health problems and subsequently the track possible effect to consumers. The aim of the present study was to evaluate the microbiological contamination rates of eels in three lakes in Latvia.

\section{Materials and Methods}

Samplings of European eels (Anguilla anguilla) were done in April and May in 2014, with 31 samples including three lakes of Latvia: Sivers lake $(n=11)$, Usma lake $(n=11)$ and Aluksne lake $(n=9)$, situated in different regions across the country with triplicated water samples from these lakes (Fig. 1).

Alive eels were obtained from fishermen and the water sample from each lake was collected in $0.5 \mathrm{~m}$ depth from the surface with $1 \mathrm{~L}$ sterile bottle. All samples were delivered into laboratory immediately after sampling and they were stored in ice during transportation. Eels were prepared for testing in the laboratory.

For detection of total bacterial count (TBC) and Enterobacteriaceae, the samples from skin, gills and intestinal tract were investigated separately. Surface

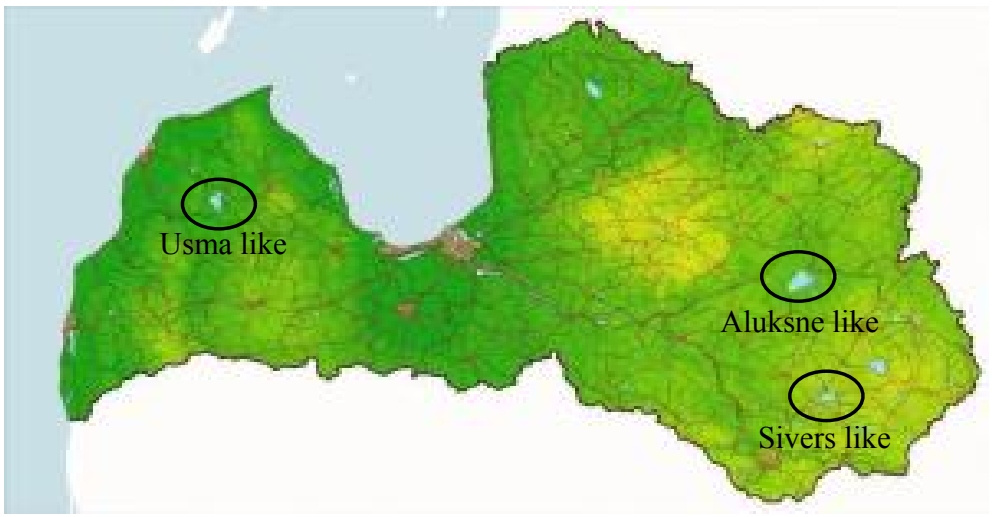

Fig. 1 Location of the lakes on the map of Latvia. 
samples of fish skin were collected with Abrasive sponge moisturized with $0.1 \%$ peptone water by covering $25 \mathrm{~cm}^{2}$ or $100 \mathrm{~cm}^{2}$ area of fish skin depending on the fish size. For collection of intestinal tract samples, the abdomen was incised and the intestinal tract containing the intestines together with their content was separated from surrounding tissues. For gill sampling, the gills were aseptically separated from the surrounding tissues. The skin, gills and intestinal tract of each fish were investigated separately. Not less than $1 \mathrm{~g}$ of gills and intestinal tract and a sponge covering $25 \mathrm{~cm}^{2}$ of skin were used for testing.

For detection of Salmonella spp. and $L$. monocytogenes, the pooled sample of skin, muscles and intestinal tract was used. Samples of each fish were investigated separately and $25 \mathrm{~g}$ of material were used for each test.

TBC and Enterobacteriaceae were detected by adding $0.1 \%$ peptone water to each sample composed of gills, skin and intestinal tract to make a 1:10 dilution. After that, serial dilutions were prepared for the investigation of samples. TBC detection was done, by transferring $1 \mathrm{~mL}$ of each serial dilution onto a plate count agar (PCA, Biolife, Milan, Italy) with two plates for each dilution and incubated for $72 \mathrm{~h}$ at 30 ${ }^{\circ} \mathrm{C}$. After incubation, the bacterial colonies were counted.

Enterobacteriaceae was detected by transferring 1 $\mathrm{mL}$ of suspension from each serial dilution onto the violet-red bile glucose agar (VRBA, Biolife) with two plates for each dilution and incubated for $24 \mathrm{~h}$ at 37 ${ }^{\circ} \mathrm{C}$. Typical colonies of Enterobacteriaceae were tested from oxidase activity and inoculated into glucose agar (Biolife) with subsequent incubation for $24 \mathrm{~h}$ at $37^{\circ} \mathrm{C}$. Only oxidase-negative and glucose-positive colonies were confirmed as Enterobacteriaceae. For Enterobacteriaceae count, typical bacterial colonies were enumerated.

For detection of Salmonella, a total amount of $25 \mathrm{~g}$ of fish samples were transferred to $225 \mathrm{~mL}$ of buffered peptone water and incubated for $18 \pm 2 \mathrm{~h}$ at $37{ }^{\circ} \mathrm{C}$. After pre-enrichment, $0.1 \mathrm{~mL}$ of suspension was transferred to Rappaport-Vassiliadis broth (Biolife) and Mueller-Kauffmann tetrathionate-novobiocin broth (Biolife) for enrichment for $24 \mathrm{~h}$ at $41.5^{\circ} \mathrm{C}$ and $37^{\circ} \mathrm{C}$, accordingly. The enriched suspension was plated out onto the brilliant green (Biolife) and xylose lysine deoxycholate (XLD, Biolife) agar for subsequent incubation for $24 \mathrm{~h}$ at $37^{\circ} \mathrm{C}$ and plates were examined for the presence of presumptive colonies.

L. monocytogenes was detected by transferring a sample of $25 \mathrm{~g}$ into Half-Fraser broth and incubated for $24 \mathrm{~h}$ at $30{ }^{\circ} \mathrm{C}$. After incubation, $0.1 \mathrm{~mL}$ of suspension was transferred to Fraser broth and incubated for $48 \mathrm{~h}$ at $37^{\circ} \mathrm{C}$. The amount of $0.1 \mathrm{~mL}$ of enriched material of Half-Fraser and Fraser broth was plated out on Oxford (Biolife) and ALOA (Biolife) agar plates and incubated for $24-48 \mathrm{~h}$ at $37{ }^{\circ} \mathrm{C}$. After incubation, agar plates were screened for the presence of presumptive colonies, which were selected for further confirmation. Presumptive colonies were stained according to Gram and checked for catalase activity, mobility and $\beta$-hemolysis. Suspicious Listeria spp. isolates were confirmed with API Listeria (BioMérieux, France).

For data analysis, microbial counts data were transformed to decimal logarithms. For evaluation of differences between means of microbial counts for TBC and Enterobacteriaceae in eels from three lakes, the Student's $t$ test analysis was applied.

\section{Results and Discussion}

The microflora of fish and other water inhabitants depends on microbiological quality of water, the particular fish, water temperature and fishing conditions. Results of TBC, Enterobacteriaceae, Salmonella spp. and L. monocytogenes in water are shown in Table 1.

The highest water TBC count was identified in Aluksne lake 1,603 CFU/mL, while the lowest was in 
Table 1 Water testing results $(\mathrm{CFU} / \mathrm{mL})$.

\begin{tabular}{llllll}
\hline Lake & Samples & TBC $(\mathrm{CFU} / \mathrm{mL})$ & $\begin{array}{l}\text { Enterobacteriaceae } \\
(\mathrm{CFU} / \mathrm{mL})\end{array}$ & $\begin{array}{l}\text { Listeria } \text { spp. } \\
(\mathrm{CFU} / \mathrm{mL})\end{array}$ & $\begin{array}{l}\text { Salmonella } \text { spp. } \\
(\mathrm{CFU} / \mathrm{mL})\end{array}$ \\
\hline Aluksne & 1 & 1,603 & $<1$ & 0 & 0 \\
Usma & 1 & 16 & 1 & 0 & 0 \\
Sivers & 1 & 86 & $<1$ & 0 & 0 \\
\hline
\end{tabular}

Table 2 The TBC in European eel (Anguilla anguilla) samples (CFU/cm²).

\begin{tabular}{|c|c|c|c|c|c|c|}
\hline \multirow{2}{*}{ Lake } & \multicolumn{2}{|c|}{ Gills } & \multicolumn{2}{|c|}{ Skin } & \multicolumn{2}{|c|}{ Gut } \\
\hline & Mean \pm SD & Range & Mean \pm SD & Range & Mean \pm SD & Range \\
\hline Aluksne & $1.14 \pm 0.45^{\mathrm{b}}$ & $0.40-1.87$ & $1.31 \pm 0.47$ & $0.85-2.00$ & $1.51 \pm 2.21$ & $0.44-5.68$ \\
\hline Usma & $2.41 \pm 0.51$ & $1.89-3.25$ & $1.50 \pm 0.36$ & $0.66-1.84$ & $1.88 \pm 1.59$ & $0.30-5.82$ \\
\hline Sivers & $4.58 \pm 0.77^{\mathrm{a}}$ & $3.36-5.51$ & $2.94 \pm 1.18^{c}$ & $1.85-4.93$ & $3.45 \pm 1.57$ & $2.56-6.37$ \\
\hline
\end{tabular}

$\mathrm{SD}=$ standard deviation. ${ }^{\mathrm{a} M e a n s} \mathrm{TBC}$ counts in gills, skin and gut samples from Sivers were significantly higher than in samples from Aluksne and Usma lakes $(P<0.05)$; ${ }^{b}$ means no differences in TBC counts among gills, skin and gut in eels from Aluksne lake were observed $(P>0.05)$; ${ }^{c}$ means skin of eels from Sivers was significantly less contaminated with TBC than gills and gut $(P<$ $0.05)$.

Usma lake $16 \mathrm{CFU} / \mathrm{mL}$. Enterobacteriaceae count did not exceed $1 \mathrm{CFU} / \mathrm{mL}$ in all lakes. All tested lake water samples were L. monocytogenes and Salmonella spp. negative.

Microbiological eel samples testing results show that TBC counts were different in all sampling sites on skin, gills and gut. TBC counts on ells gills, skin and gut were from $0.40 \mathrm{CFU} / \mathrm{cm}^{2}$ to $5.51 \mathrm{CFU} / \mathrm{cm}^{2}$, from $0.66 \mathrm{CFU} / \mathrm{cm}^{2}$ to $4.93 \mathrm{CFU} / \mathrm{cm}^{2}$ and from 0.30 $\mathrm{CFU} / \mathrm{cm}^{2}$ to $6.37 \mathrm{CFU} / \mathrm{cm}^{2}$, respectively, depending on lake of origin (Table 2), which shows that the bacterial load (TBC) is not high according to Nikolajeva [7].

Enterobacteriaceae did not exceed $1 \mathrm{CFU} / \mathrm{mL}$ in any of the lakes. All the tested samples were $L$. monocytogenes and Salmonella spp. negative.

The mean TBC counts in gills, skin and gut were significantly higher in eels from Sivers than in samples from Aluksne and Usma lakes $(P<0.05)$. This indicates than fish originated from different lakes may show different numbers of TBC counts and fish origin may have impact in microbiological condition of fish. Despite of fish testing results showed the highest TBC counts were found in water from Aluksnes, it is generally accepted that microbiological load of freshwater fish depends on water condition and temperature. However, Gonzalez et al. [17] found that composition of water microflora did not influence fish microflora and had no significance effect on fish microflora.

There were no significant differences between TBC counts for gills, skin and gut samples in eels from Aluksne and Usma lake $(P>0.05)$, however, skin of eels from Sivers was significantly less contaminated with TBC than gills and gut $(P<0.05)$. TBC counts of fish were acceptable and indicated that eels yielded the same counts of organisms as another fishes, such as wild brown trout (Salmo trutta), wild pike (Esox lucius), Silver bream (Blicca bjoerkna), European perch (Perca fluvialitis), aquacultured rainbow trout (Oncorhynchus mykiss) and tilapia (Oreochromis spp.) in the previous studies [7, 17-19]. Results of this study indicate that mesophiles counts for wild and farmed fishes from cold and unpolluted waters varies from $10^{2} \mathrm{CFU} / \mathrm{cm}^{2}$ to $10^{5} \mathrm{CFU} / \mathrm{cm}^{2}$ for skin and $10^{3}$ $\mathrm{CFU} / \mathrm{cm}^{2}$ to $10^{6} \mathrm{CFU} / \mathrm{cm}^{2}$ for gut, respectively [17].

Enterobacteriaceae counts on the gills, skin and gut of eel ranged from $0 \mathrm{CFU} / \mathrm{cm}^{2}$ to $2.47 \mathrm{CFU} / \mathrm{cm}^{2}$, from $0 \mathrm{CFU} / \mathrm{cm}^{2}$ to $4.30 \mathrm{CFU} / \mathrm{cm}^{2}$ and from $0 \mathrm{CFU} / \mathrm{cm}^{2}$ to $1.72 \mathrm{CFU} / \mathrm{cm}^{2}$ depending on lake of origin (Table 3). The highest mean counts of Enterobacteriaceae in gills $\left(1.64 \mathrm{CFU} / \mathrm{cm}^{2}\right)$ and skin $\left(3.20 \mathrm{CFU} / \mathrm{cm}^{2}\right)$ were found in 
Table 3 The Enterobacteriaceae in European eel (Anguilla anguilla) samples (CFU/cm²).

\begin{tabular}{|c|c|c|c|c|c|c|}
\hline \multirow{2}{*}{ Lake } & \multicolumn{2}{|c|}{ Gills } & \multicolumn{2}{|c|}{ Skin } & \multicolumn{2}{|c|}{ Gut } \\
\hline & Mean \pm SD & Range & Mean \pm SD & Range & Mean \pm SD & Range \\
\hline Aluksne & $0.03 \pm 0.11^{\mathrm{a}}$ & $0.00-0.30$ & $0.03 \pm 0.11$ & $0.00-0.30$ & $0.38 \pm 0.71$ & $0.00-2.26$ \\
\hline Usma & $1.40 \pm 0.51$ & $0.70-2.11$ & 0.00 & 0.00 & $2.43 \pm 2.44$ & $0.00-4.15$ \\
\hline Sivers & $1.64 \pm 0.42^{\mathrm{a}}$ & $1.11-2.47$ & $3.20 \pm 1.28$ & $1.34-4.30$ & $0.20 \pm 0.50$ & $0.00-1.72$ \\
\hline
\end{tabular}

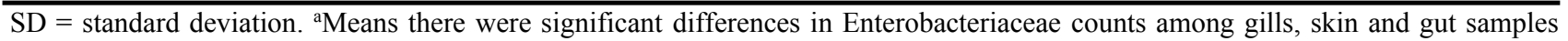
from different lakes $(P<0.05)$.

samples from Sivers, but the highest mean counts of Enterobacteriaceae in gut $\left(2.43 \mathrm{CFU} / \mathrm{cm}^{2}\right)$ was in samples from Usma lake.

The mean counts of Enterobacteriaceae were the highest in skin in comparison with gut and gills and there were significant differences in Enterobacteriaceae counts among gills, skin and gut samples from different lakes $(P<0.05)$. The authors' results are in accordance with Junior et al. [10] who reported the highest numbers of coliforms on skin than on gut in tilapia, and with Gonzalez et al. [17] who evaluated Enterobacteriaceae in gills, gut and skin samples of wild brown trout (Salmo trutta), wild pike (Esox lucius) and aquacultured rainbow trout (Oncorchynchus mykiss) in Spain. Increased counts of Enterobacteriaceae in gills and skin samples of eels corresponded to results of increased TBC counts for eel samples from Sivers lake, however Enterobacteriaceae counts in Aluksne and Sivers water were lower than detection limits.

All tested samples were Salmonella spp. and $L$. monocytogenes negative. Results on the prevalence of Salmonella spp. are in accordance to previous studies, and the Salmonella spp. was not isolated from wild and aquacultured fishes across Europe [15, 19, 20]. In contrast, the presence of Salmonella spp. in freshly caught and marketed fish were reported in Africa in Asia and the presence of Salmonella spp. in fish was linked to poor hygiene of water source and handling of fish during fishing, processing and marketing [21, 22].

L. monocytogenes was isolated from freshwater and marine fish more frequently than Salmonella spp. Results of this study were in agreement with Davies et al. [15], Gonzalez et al. [17], and Pullela et al. [18], who did not find L. monocytogenes in wild and aquacultured fish samples. However, Vogel et al. [23] and Miettinen and Wirtanen [24] reported 8.6\% and $14.6 \%$ prevalence of L. monocytogenes in Denmark and Finland, respectively. Absence of $L$. monocytogenes in tested samples was linked to good aquacultural practice [18]. Since tested water samples in this study did not reveal the presence of $L$. monocytogenes, these findings may be attributed to good microbiological quality of lake water and indicate an unpolluted lake environment. In general, absence of Salmonella spp. and L. monocytogenes in tested samples shows that freshly caught eels do not pose public health concerns and are safe for consumption.

\section{Conclusions}

Microbiological contamination rates of European eels (Anguilla anguilla) in the present study were typical for wild fish in unpolluted environment and were comparable with microbiological contamination tares of another freshwater and marine fishes. Testing of gills, skin and gut of eel did not reveal specific contamination pattern, which could be typical for European eel. Additionally, foodborne pathogens, such as Salmonella spp. and L. monocytogenes, were not found in eel samples, indicating that fish are safe for consumption.

\section{Acknowledgments}

This study was conducted within the European Social Fund Project 2013/0016/1DP/1.1.1.2.0/13/APIA/VIAA/055. 


\section{References}

[1] Wafaa, M. K. B., Walaa, A. H., and Amani, F. A. 2011. "Detection of Salmonella and Vibrio Species in Some Seafood in Alexandria." Journal of American Sciences 7 (9): 663-8.

[2] Adebayo-Tayo, B. C., Odu, N. N., and Okonko, I. O. 2012. "Microbiological and Physiochemical Changes and Its Correlation with Quality Indices of Tilapia Fish (Oreochromis niloticus) Sold in Itu and Uyo Markets in Akwa Ibom State, Nigeria." New York Science Journal 5 (4): $38-45$.

[3] Latvijas Statistika. 2013. "Household Expenditure on Food Monthly Comprises LVL 55 Per Capita." Accessed August 2, 2013. http://www.csb.gov.lv/en/notikumi/ Household-expenditure-food-monthly-comprises-lvl-55-c apita-39101.html. (in Latvian)

[4] European Food Safe Authority (EFSA) and European Centre for Disease Prevention and Control (ECDC). 2014. "The European Union Summary Report on Trends and Sources of Zoonoses, Zoonotic Agents and Foodborne Outbreaks in 2012." EFSA Journal 12 (2): 3547.

[5] Sathware, N. G., Paterl, K. G., Vyas, J. B., Patel, S., Trivedi, M. R., Dave, L. M., Madia, M. M., Kulkarni, P. K., Parikh, D. J., and Saiyed, H. N. 2007. "Chromium Exposure Study Inchemical Based Industry." Journal of Environmental Biology 28 (2): 405-8.

[6] Emikpe, B. O., Adebisi, T., and Adedeji, O. B. 2011. "Bacteria Load on the Skin and Stomach of Clarias Gariepinus and Oreochromis Niloticus from Ibadan, South West Nigeria: Public Health Implications.” Journal of Microbiology and Biotechnology Research 1 (1): 52-9.

[7] Nikolajeva, V. 2011. Food Microbiology. Riga: LU Academic Publishers, 130. (in Latvian)

[8] Huss, H. H. 1995. Quality and Quality Changes in Fresh Fish. Rome: Food Agriculture Organisation (FAO), 348.

[9] Miettinen, H., and Wirtanen, G. 2006. "Ecology of Listeria spp. in a Fish Farm and Molecular Typing of Listeria monocytogenes from Fish Farming and Processing Companies." International Journal of Food Microbiology 112 (2): 138-46.

[10] Junior, P. G., Assuncao, A. W. A., Baldin, J. C., and Amaral, L. A. 2014. "Microbiological Quality of Whole and Filleted Shelf-Tilapia." Aquaculture 433: 196-200.

[11] Sallam, K. I. 2007. "Chemical, Sensory and Shelf Life Evaluation of Sliced Salmon Treated with Salts of Organic Acids." Food Chemistry 101 (2): 592-600.

[12] Kirby, M. F., Bignell, J., Brown, E., Craft, J. A., Davies, I., Dyer, R. A., Feist, S. W., Jones, G., Matthiessen, P., Megginson, C., Robertson, F. E., and Robinson, C. 2003. "The Presence of Morphologically Intermediate Papilla Syndrome in United Kingdom Populations of Sand Goby
(Pomatoschistus spp): Endocrine Disruption?" Environmental Toxicology and Chemistry 22 (2): 239-51.

[13] Chattopadhyay, P. 2000. "Fish —Catching and Handling." In Encyclopedia of Food Microbiology, edited by Robinson, R. K. Vol. 2. London: Academic Press, 1547.

[14] Novotny, L., Dvorska, L., Lorencova, A., Beran, V., and Pavlik, I. 2004. "Fish: A Potential Source of Bacterial Pathogens for Human Beings." Veterinary Medicine-Czech 49 (9): 343-58.

[15] Davies, A. R., Capell, C., Jehanno, D., Nychas, G. J. E., and Kirby, R. M. 2001. "Incidence of Foodborne Pathogens on European Fish." Food Control 12 (2): 67-71.

[16] Yucel, N., and Balci, S. 2010. "Prevalence of Listeria Aeromonas and Vibrio Species in Fish Used for Human Consumption in Turkey." Journal of Food Protection 73 (2): 380-4.

[17] Gonzalez, C., J., Lopez-Diaz, T. M., Garcia-Lopez, M., L., Prieto, M., and Otero, A. 1999. "Bacterial Microflora of Wild Brown Trout (Salmo trutta), Wild Pike (Esox lucius) and Aquacultured Rainbow Trout (Oncorhynchus mykiss)." Journal of Food Protection 62 (11): 1270-7.

[18] Pullela, S., Fernandes, C. F., Flick, G. J., Libey, G. S., Smith, S. A., and Coale, C. W. 1998. "Indicative and Pathogenic Microbiological Quality of Aquacultured Finfish Grown in Different Production Sistems." Journal of Food Protection 61 (2): 205-10.

[19] Terentjeva, M., Eizenberga, I., Novoslavskij, A., Strazdina, V., Valcina, O., Osmjana, J., and Berzins, A. 2015. "Bacterial Microflora of Freshwater Fish Orginated from Usmas Lake in Latvia." Journal of Microbiology, Biotechnology and Food Sciences 4: 74-7.

[20] Hudecova, K., Buchtova, H., and Steinhauserova, I. 2010. "The Effects on Modified Atmosphere Packaging on the Microbiological Properties of Fresh Common Carp (Cyprinus carpio).” Acta Veterinaria Brno 79: 93-100.

[21] Onyango, D. M., Wandili, S., Kakai, R., and Waindi, E. N. 2009. "Isolation of Salmonella and Shigella from Fish Harvested from the Winam Gulf of Lake Victoria, Kenya”. Journal of Infection in Developing Countries 3 (2): 99-104.

[22] Budiati, T., Rusul, G., Wan-Abdullah, W. N., Arip, Y. M., Ahmad, R., and Thong, K. L. 2013. "Prevalence, Antibiotic Resistance and Plasmid Profiling of Salmonella in Catfish (Clarias gariepinus) and Tilapia (Tilapia mossambica) Obtained from Wet Markets and Ponds in Malaysia." Aquaculture 372-375: 127-32.

[23] Vogel, B. F., Huss, H. H., Ojeniji, B., Ahrens, P., and Gram, L. 2001. "Elucidation of Listeria monocytogenes Contamination Routes in Cold-Smoked Salmon Processing Plants Detected by DNA-Based Typing 
Methods." Applied and Environmental Microbiology 67 (6): 2586-95

[24] Miettinen, H., and Wirtanen, G. 2005. "Prevalence and
Location of Listeria monocytogenes in Farmed Rainbow Trout." International Journal of Food Microbiology 104 (2): 135-43. 